\title{
ZAKAT PRODUKTIF SEBAGAI ALTERNATIF KREDIT MIKRO DALAM PENGEMBANGAN USAHA MUSTAHIK (STUDI KASUS UPZ UNIB)
}

\author{
Reno Adi Saputra ${ }^{1)}$, Ratu Eva Febriani ${ }^{2)}$ \\ ${ }^{1}$ Jurusan Ekonomi Pembangunan Fakultas Ekonomi Dan Bisnis Universitas Bengkulu \\ Email: renoadiisaputra@gmail.com \\ 2 Jurusan Ekonomi Pembangunan Fakultas Ekonomi Dan Bisnis Universitas Bengkulu \\ Email: ratuevafebriani@unib.ac.id
}

\begin{abstract}
This research aims to know the impact of zakat funds allocation to the business economy of the recipent (Mustahik) given by UPZ Unib, the progress of capital, the progress $t$ of omset and the progess of advantages. The data used are primary data. The method analysis used in this research is descriptive analysis quantitative. The results of this research show that the allocation of produvtive zakat funds have impact on business omset with an average progress capital of $43.53 \%$, the progress of business omset with an average of $41.71 \%$, and the progress of average business profits $37.75 \%$
\end{abstract}

Keywords : Capital, Mustahik Business, Omset, Professional zakat, Profit, UPZ Unib

\section{PENDAHULUAN}

Ketidaksamaan pola kepemilikan sumberdaya akan menimbulkan ketimpangan dalam distribusi pendapatan, dan pada umumnya masyarakat yang hanya memiliki sumberdaya terbatas dan berkualitas rendah berada pada garis kemiskinan. Kondisi ketimpangan antara masyarakat kaya dengan masyarakat miskin menurut Hafidhuddin (2007) merupakan potret dari kemiskinan struktural. Artinya, kemiskinan yang ada bukan disebabkan oleh lemahnya etos kerja, melainkan disebabkan oleh ketidakadilan sistem. Kemiskinan model ini sangat membahayakan kelangsungan hidup sebuah masyarakat, sehingga diperlukan adanya sebuah mekanisme yang mampu mengalirkan kekayaan yang dimiliki oleh kelompok masyarakat mampu (the have) kepada kelompok masyarakat yang tidak mampu.

Menurut Kiyosaki dalam Muhammad (2006), para peneliti telah banyak melakukan penelitian dengan waktu yang cukup lama, dan telah banyak mengeluarkan dana dan juga telah banyak konsep-konsep yang rumit dalam usaha untuk menanggulangi kemiskinan dan pemerataan pembangunan baik skala nasional maupun global. Hasil penelitian yang telah banyak dilakukan memiliki kesimpulan yang sama, yaitu tidak ada kesesuaian terhadap pengorbanan dana yang telah di keluarkan. Pada kenyataannya pengurangan kemiskinan semakin jauh dari harapan dan cenderung masih memelihara ketimpangan antara masyarakat kaya dengan masyarakat miskin, bahkan pertumbuhan ekonomi dunia semakin tidak baik dan rapuh.

Di Indonesia kemiskinan merupakan masalah klasik yang terus terjadi sampai saat ini. Berdasarkan data dari Badan Pusat Statisik (BPS), dalam bulan maret 2018 presentase kemiskinan perkotaan 7,02 \% dan pedesaan mencapai 9,82\%. Persoalan kemiskinan merupakan salah satu persoalan krusial yang tengah dihadapi oleh bangsa Indonesia saat ini.

Ketidaksamaan pola kepemilikan sumberdaya akan menimbulkan ketimpangan dalam distribusi pendapatan, dan pada umumnya masyarakat yang hanya memiliki sumberdaya terbatas dan berkualitas rendah berada padagaris kemiskinan. Pada prinsipnya disetiap negara atau wilayah manapun juga selalu ada usaha pemerintah untuk menghindari ketimpangan dalam pendapatan 
yang dapat menimbulkan kesenjangan sosial dan ketidakstabilan dalam masyarakat, namun sampai saat ini belum terlalu signifikan hasil yang diharapkan dari usaha-usaha tersebut. Berbagai provinsi di Indonesia juga banyak mengalami permasalahan yang sama tentang kemiskinan dan ketimpangan pendapatan, salah satunya adalah Bengkulu. Menurut BPS laju pertumbuhan PDRB perkapita pada tahun 2016 adalah 3,64 dan pada tahun 2017 adalah 3,39. Pada tahun yang sama, presentase penduduk miskin di Provinsi Bengkulu juga tinggi yaitu pada tahun 2016 15,23 dan 17,23 pada tahun 2017.

Banyak faktor yang dalam suatu wilayah dapat digunakan untuk menentukan kebijakan-kebijakan yang dilakukan oleh pemerintah sebagai upaya mengurangi kemiskinan dan pemerataan pembangunan terutama pemerintah daerah Provinsi Bengkulu, yaitu melalui pendekatan geografis, keberagaman budaya, dan juga kepercayaan yang dianut oleh penduduknya. Pada praktiknya pemerintah jarang sekali membuat kebijakan berdasarkan atas budaya, kepercayaan yang dianut oleh masyarakatnya, padahal menurut Veblen dalam Ahmad (2013), manusia sebagai pembuat keputusan tidak sepenuhnya dilatarbelakangi oleh motif ekonomi, tetapi manusia dipengaruhi oleh faktor lingkungan seperti adat istiadat dan kepercayaan nya juga lembaga-lembaga tertentu.

Ada beberapa alasan mengapa ekonomi islam mempunyai kesempatan yang besar untuk terus berkembang di Indonesia dan terutama di Bengkulu, yaitu adanya ketimpangan sosial antara masyarakat kaya dan masyarakat miskin. Salah satu upaya dalam menurunkan angka kemiskinan adalah dengan melakukan pemerataan pendapatan antara golongan berkemampuan dengan golongan tidak mampu. Upaya pemerataan pendapatan yang dikenal dalam islam adalah zakat, infaq, shodaqah dan wakaf.

Infaq adalah seluruh bentuk pembelanjaan atau pengerahan potensi/kemampuan kita dalam bentuk materil untuk kepentingan umat islam dan hukumnya sunnah juga tidak terdapat besaran dari jumlah yang harus dikeluarkan, selanjutnya shodaqah juga pengerahan potensi/kemampuan baik materil maupun non materil dan hukumnya adalah sunnah, juga tidak memiliki besaran berapa yang harus dikeluarkan, kemudian wakaf adalah melepaskan materil atau harta yang diwakafkan dari kepemilikan wakif, setelah sempurna prosedur perwakafan, dan terakhir zakat, Gusfahmi (2007). Zakat merupakan instrumen yang paling detail mengenai apa, siapa, kapan, berapa dan bagaimana menyelenggarakannya, zakat memiliki hukum yang wajib, dalam pengeluaran zakat juga ditentukan berapa besaran yang harus dikeluarkan berdasarkan dari jenis zakatnya, Gusfahmi (2007).

Dalam menghimpun dana zakat profesi Badan Amil Zakat Provinsi Bengkulu melibatkan dan bekerjasama dengan pemerintah, Lembaga Amil Zakat, perguruan tinggi dan lembaga swadaya masyarakat. Salah satu perguruan tinggi terbesar di Provinsi Bengkulu adalah Universitas Bengkulu (UNIB). UNIB memiliki potensi zakat profesi yang sangat besar, tercatat pada awal tahun 2019 karyawan dan dosen muslim baik PNS atau non PNS adalah berjumlah 1515 orang. Dalam memaksimalkan pengelolaan dana zakat yang ada, Universitas Bengkulu (UNIB) sudah terbentuk Unit Pengumpul Zakat (UPZ), yang diharapkan mampu mengelola potensi zakat yang ada di UNIB. Berikut adalah dana zakat yang berhasil dihimpun oleh UPZ UNIB pada tahun 2017 dan 2018.

Tabel 1 Data Penerimaan Dan Penyaluran Zakat Tahun 2017- 2018

\begin{tabular}{llll}
\hline No & Tahun & Penerimaan & Penyaluran \\
\hline 1 & 2017 & Rp. 936,553,533 & Rp. 628,011,239 \\
2 & 2018 & Rp. 1,003,338,217 & Rp. 749,500,839
\end{tabular}

Sumber : Laporan keuangan UPZ Unib 2017 dan 2018 
Berdasarkan tabel 1 maka dapat dilihat bahwa pada tahun 2017 ke tahun 2018 mengalami kenaikan pada penerimaan zakat sehingga penyalurannya juga mengalami peningkatan, dimana penerimaan sebesar Rp. 1,003,338,217. dan penyalurannya sebesar Rp. 749,500,839, diantara penyebabnya adalah adanya sisa penerimaan yang tidak tersalurkan pada tahun sebelumnya dan juga bertambahnya pemberi zakat atau muzakki.

UPZ UNIB menghimpun dana zakat yaitu zakat penghasilan atau zakat profesi para Civitas Akademika yang ada di Universitas Bengkulu, baik Dosen, karyawan dan lainya, UPZ mengelola dan mendistribusikan dana zakat yang terhimpun kepada masyarakat yang ada di Kota Bengkulu. Salah satu jenis penyaluran dana zakat adalah penyaluran yang bersifat produktif. Penyaluran yang bersifat produktif merupakan upaya yang dampaknya jangka panjang dan diharapkan penerima menjadi mandiri secara mental dan finansial hingga dapat mengurangi kemiskinan dengan meningkatnya pendapatan. penyaluran produktif diharapkan dapat memberikan efek multiplier kepada penerima.

Penyaluran yang bersifat produktif disalurkan dalam bentuk modal usaha. Bantuan modal usaha diberikan kepada para mustahik yang telah memiliki usaha dan memenuhi kriteria yang telah ditetapkan oleh UPZ UNIB. Penyaluran dana zakat terhadap usaha ekonomi mustahik diharapkan dapat meningkatkan kesejahteraan dan mengurangi kemiskinan mustahik melalui usaha yang mereka jalankan. Pada tahun 2017 penyaluran yang bersifat produktif yaitu bantuan modal usaha sebesar 6.29\%, dan pada tahun 2018 dana yang disalurkan untuk bantuan modal usaha yang diberikan kepada mustahik yang telah memiliki usaha mengalami peningkatan yaitu sebesar $8.51 \%$. peningkatan penyaluran dana produktif untuk bantuan modal usaha diharapkan mampu meningkatkan ekonomi mustahik dan mengurangi kemiskinan.

Usaha yang dijalankan oleh mustahik bisa dikatakan sebagai salah satu alternatif solusi masyarakat untuk dapat meningkatkan pendapatan, yaitu melalui kegiatan usaha yang berkarakteristik informal. Dana yang disalurkan oleh UPZ Unib digunakan untuk bantuan modal usaha dalam menjalankan kegiatan usaha mustahik, diharapkan dengan bertambahnya modal akan menambah omset dan juga keuntungan yang didapatkan oleh mustahik. Dengan adanya usaha yang bergerak di sektor informal ini, maka persoalan kemiskinan dapat dikurangi karena implikasi yang diharapkan adalah terjadinya peningkatan pendapatan, yang dapat mereka gunakan untuk memenuhi kebutuhan pokoknya.

\section{LANDASAN TEORI}

\section{Konseptual Zakat}

Menurut terminologi syariat (istilah), zakat adalah nama bagi sejumlah harta tertentu yang telah mencapai syarat tertentu pula yang diwajibkan oleh Allah untuk dikeluarkan dan diberikan kepada orang-orang yang berhak menerimanya. Dari makna bahasa dan istilah, dijelaskan bahwa setiap harta yang dikeluarkan zakatnya akan menjadi suci, berkah, tumbuh dan terpuji, dan zakat juga akan mensucikan orang yang mengeluarkannya. Zakat akan menyucikan orang yang telah mengeluarkanya dan menumbuhkan pahalanya (QS. At-Taubah :103 dan ar-Rum :39). Di dalam kitab-kitab hukum (fiqih) islam, harta kekayaan yang wajib dizakati digolongkan dalam kategori:

a. emas, perak, dan uang (simpanan) (QS. At-Taubah/9:34-35)

b. barang yang diperdagangkan (QS. Al-Baqarah/2:267)

c. hasil peternakan (QS. Al-Baqarah/2:267)

d. hasil tambang dan barang temuan (QS. Al-Baqarah/2:267)

Menurut Qardhawi, dalam Muhammad (2002), menyatakan bahwa beberapa jenis harta kekayaan yang wajib dikeluarkan zakatnya yang belum ditegaskan lain oleh dalil, maka ahli fiqih melakukan ijtihad untuk menentukan statusnya dengan menghasilkan bermacam-macam pendapat sempit, luas 
dan sedang, salah satunya adalah zakat pendapatan dari seseorang yang melakukan usaha yang membawa keuntungan atau disebut dengan zakat profesi. Zakat profesi adalah zakat yang dikenakan kepada seseorang karena profesinya. Profesi sendiri menurut kamus Besar Bahasa Indonesia di sebutkan profesi adalah bidang pekerjaan yang dilandasi keahlian (keterampilan, kejujuran, dan sebagainya) tertentu. Jadi zakat profesi adalah zakat yang dikeluarkan dari hasil usaha yang halal, mampu mendatangkan uang yang banyak dengan atau melalui keahlian tertentu.

Pendayagunaan dalam zakat berkaitan dengan bagaimana cara pendistribusianya, berasal dari kata guna yang berarti manfaat. Pendayagunaan adalah bagaimana cara mendatangkan hasil dan manfaat yang lebih besar dan lebih baik. Dalam undang-undang No. 23 tahun 2011 pasal 27 tentang zakat, dijelaskan mengenai pendayagunaan, yaitu:

1. zakat dapat didayagunakan untuk usaha produktif dalam rangka penanganan fakir miskin dan peningkatan kualitas umat.

2. Pendayagunaan zakat untuk usaha produktif sebagaimana dimaksud pada pada ayat (1) dilakukan apabila kebutuhan dasar mustahik sudah terpenuhi.

Dilihat dari unit usaha yang sangat banyak di Indonesia, pada semua sektor ekonomi dan kontribusinya terhadap penciptaan kesempatan kerja dan sumber pendapatan, khususnya didaerah pedesaan dan bagi rumah tangga berpendapatan rendah, tidak dapat diingkari betapa pentingnya Usaha Mikro Kecil dan Menengah (UMKM). Selain itu, selama ini kelompok usaha tersebut juga berperan sebagai salah satu motor penggerak bagi pembangunan ekonomi dan komunitas lokal (Tambunan, 2002).

\section{Teori Produksi dan Biaya}

Produksi sering diartikan sebagai penciptaan guna, dimana kemampuan barang atau jasa untuk memenuhi kebutuhan manusia. Dalam pengertian ekonomi dapat dikatakan bahwa produksi adalah kegiatan yang menghasilkan barang yang bernilai ekonomi dalam jumlah tertentu dan pada suatu waktu tertentu. Menurut (Soeharto, 2007) produksi adalah suatu kegiatan untuk mengingkatkan manfaat dengan cara mengkombinasikan faktor-faktor produksi seperti kapital, tenaga kerja, dan teknologi.

Dalam kegiatan produksi terdapat biaya-biaya yang dikeluarkan oleh perusahaan untuk memperoleh faktor-faktor produksi dan bahan-bahan mentah yang akan digunakan untuk menciptakan barang-barang yang akan menghasilkan manfaat dan keuntungan bagi perusahaan tersebut. Dalam teori ekonomi, berbagai jenis perusahaan dipandang sebagai unit kegiatan usaha yang mempunyai tujuan yang sama yaitu "mencapai keuntungan yang maksimum". Untuk tujuan itu, perusahaan mengatur penggunaan faktor produksi dengan cara paling efisien.

\section{Pendapatan Usaha}

Pendapatan merupakan keseluruhan pendapatan informal, pendapatan informal serta pendapatan subsistem (Sumardi, 1997). Pendapatan formal adalah penghasilan yang diperoleh seseorang melalui pekerjaan poko, sedangkan pendapatan indormal yakni pendapatan yng diperoleh melalui pekerjaan sampingan dan pendapatan subsistem diartikan sebagai penghasilan yang diperoleh dari produksi sendiri dan dipergunakan untuk kepentingan sendiri, tanpa melalui proses pasar. Menurut Mankiw (2003), pendapatan adalah seluruh penghasilan yang diterima oleh sebuah perusahaan dari penjualan (output).

Rumus untuk menghitung pendapatan adalah :

$$
\mathrm{TR}=\mathrm{P} \times \mathrm{Q}
$$




\section{Biaya Produksi}

Sedangkan untuk biaya produksi sendiri menurut (Mulyadi. 1995) biaya produksi merupakan biaya-biaya yang terjadi untuk mengolah bahan baku menjadi produk jadi yang siap untuk dijual. Biaya produksi juga merupakan biaya-biaya yang berhubungan dengan produksi suatu item, yaitu jumlah dari bahan langsung dan biaya overhead pabrik (Amin Widjaya, 1993).

Rumus untuk menghitung biaya adalah :

$$
\mathrm{TC}=\mathrm{TFC}+\mathrm{TVC}
$$

\section{Laba/Keuntungan}

Laba merupakan indikasi apakah perusahaan atau usaha tersebut berhasil atau tidak. Laba yang diperoleh akan menentukan keputusan yang diambil oleh perusahaan atau pemilik usaha atau pemilik kepentingan. Menurut Mankiw (2003), laba atau profit adalah pendapatan total dikurangi dengan biaya total dari perusahaan atau biaya usaha.

Rumus dalam menghitung keuntungan:

$$
\text { Profit }=\mathrm{TR}-\mathrm{TC}
$$

\section{METODE PENELITIAN}

Jenis penelitian ini adalah penelitan deskriptif kuantitatif. Penelitian deskriptif kuantitatif merupakan penelitian yang berusaha menggambarkan suatu gejala sosial. Dengan kata lain penelitian ini bertujuan untuk menggambarkan sesuatu yang tengah berlangsung pada saat studi. Metode deskriptif tertuju pada pemecahan masalah yang ada pada masa sekarang dengan cara menuturkan dan menafsirkan data. Metode kuantitatif ini memberikan informasi yang lengkap sehingga bermanfaat bagi ilmu pengetahuan. Data yang digunakan dalam penelitian ini adalah data primer. Data primer merupakan data yang diperoleh langsung dengan memberikan kuisioner atau daftar pertanyaan kepada pengelola, atau penerima zakat. Metode analisis yang digunakan untuk mendapatkan hasil penelitian dari segi teori empiris adalah metode analisis deskriftif kualitatif, yang merupakan suatu metode yang digunakan untuk mengumpulkan, mengolah, dan menyajikan data kedalam bentuk tabel.

Demi mempermudah melihat perkembangan dari penelitian ini maka peneliti menampilkan data dari setiap kategori yang menjadi indikator dengan alat sebagai berikut:

Analisis dampak alokasi dana zakat terhadap usaha ekonomi mustahik

Demi mempermudah melihat perkembangan dari penelitian ini maka peneliti menampilkan data presentase perkembangan dari setiap kategori yang menjadi indikator perkembangan usaha mustahik yang menerima bantuan dana zakat produktif. Untuk mengetahui perkembangan usaha mustahik dari modal usaha, pendapatan usaha, dan keuntungan usaha, yaitu :

Perkembangan modal usaha mustahik

Modal Setelah Menerima - Modal Sebelum Menerima

Modal Sebelum Menerima

$x 100 \%$

Perkembangan Omset usaha mustahik 


\section{$\frac{\text { Omset Setelah Menerima }- \text { Omset Sebelum Menerima }}{\text { Omset Sebelum Menerima }} \times 100 \%$}

Perkembangan keuntungan usaha mustahik

$$
\frac{\text { Keuntungan Setelah Menerima }- \text { Keuntungan Sebelum Menerima }}{\text { Keuntungan Sebelum Menerima }}
$$

\section{HASIL DAN PEMBAHASAN}

Dalam menjalankan fungsinya terutama tentang penghimpunan dana zakat Badan Amil Zakat Nasional Provinsi Bengkulu memiliki Unit Pengumpul Zakat (UPZ). Di Universitas Bengkulu dibentuk Unit pengumpul Zakat Universitas Bengkulu (UPZ Unib). Berdasarkan SK Baznas Provinsi Bengkulu No. 025/BAZNAS-Prov.Bkl/XI/2016, UPZ UNIB berkewajiban untuk mengumpulkan zakat dari para karyawan dan Dosen di lingkungan Universitas Bengkulu yang telah berpenghasilan senilai 85 gram emas dalam kurun waktu satu tahun, zakatnya 2,5\% dan bagi yang belum mencapai nishab dapat dipungut infaq. Kemudian dalam rangka penyalurannya, UPZ UIB akan dibentuk tim penyalur. Berikut adalah dana zakat yang berhasil dihimpun oleh UPZ UNIB pada tahun 2017 dan 2018.

Tabel 2. Data Penerimaan Dan Penyaluran Zakat Tahun 2017- 2018

\begin{tabular}{llcl}
\hline No & Tahun & Penerimaan & Penyaluran \\
\hline 1 & 2017 & Rp. 936,553,533 & Rp. 628,011,239 \\
2 & 2018 & Rp. 1,003,338,217 & Rp. 749,500,839 \\
\hline
\end{tabular}

Sumber: Laporan keuangan UPZ UNIB 2017 dan 2018

Dana zakat disalurkan kepada mustahik atau orang-orang yang berhak menerima zakat dalam beberapa bentuk kegiatan, yaitu sebagai berikut:

Tabel 3. Data Penyaluran Dana Zakat UPZ 2017 - 2018

\begin{tabular}{clcc}
\hline No & Penyaluran & 2017 & 2018 \\
\hline 1 & Fakir Miskin & $0.16 \%$ & $8.75 \%$ \\
2 & Jompo/Lansia & $6.27 \%$ & - \\
3 & Bedah Rumah & $0.48 \%$ & $1.33 \%$ \\
4 & Beasiswa & $45.23 \%$ & $37.18 \%$ \\
5 & Produktif & $6.29 \%$ & $8.61 \%$ \\
6 & Miskin & $8.74 \%$ & $1.79 \%$ \\
7 & Kegiatan Mahasiswa & $3.00 \%$ & $11.04 \%$ \\
8 & TPQ & $8.99 \%$ & $5.12 \%$ \\
9 & Marbot & $5.73 \%$ & $4.80 \%$ \\
10 & Yayasan & $5.16 \%$ & $3.35 \%$ \\
11 & Sosialisasi & $0.13 \%$ & $0.13 \%$ \\
12 & Masjid & $0.10 \%$ & $0.42 \%$ \\
13 & Mualaf & $0.37 \%$ & $0.83 \%$ \\
14 & Lainnya & $9.35 \%$ & $16.65 \%$ \\
\hline
\end{tabular}

Sumber: Laporan keuangan UPZ UNIB 2017 dan 2018 
Salah satu jenis penyaluran dana zakat adalah penyaluran yang bersifat produktif. Penyaluran yang bersifat produktif merupakan upaya yang dampaknya jangka panjang dan diharapkan penerima menjadi mandiri secara mental dan finansial hingga dapat mengurangi kemiskinan dengan meningkatnya pendapatan. Tujuan dari penyaluran dana zakat produktif ini adalah untuk membantu mustahik yang memiliki usaha namun kesulitan dalam permodalan, karena lembaga keuangan cenderung memberikan bunga cukup besar sehingga akan menyulitkan para mustahik dalam mengembalikan dana tersebut.

Berdasarkan hasil penelitian maka karakteristik usia responden mulai dari 34 hingga 62 tahun, dapat dilihat pada tabel berikut:

Tabel 4 Karakteristik Responden berdasarkan Usia

\begin{tabular}{ccc}
\hline Kelas Interval & Jumlah & Persen \\
\hline $34-38$ & 3 & $14.29 \%$ \\
$39-42$ & 7 & $33.33 \%$ \\
$43-46$ & 2 & $9.52 \%$ \\
$47-50$ & 5 & $23.81 \%$ \\
$51-54$ & 1 & $4.76 \%$ \\
$55-58$ & 2 & $9.52 \%$ \\
$59-62$ & 1 & $4.76 \%$ \\
\hline Total & 21 & $100.00 \%$ \\
\hline
\end{tabular}

Sumber: hasil penelitian bulan April 2019

Dari Tabel 4. Dapat dilihat bahwa usia responden mulai dari 30 tahun sampai 61 tahun. Dari tabel terlihat indikasi bahwa mayoritas responden masih memiliki kesempatan untuk merubah hidup mereka menjadi lebih baik lagi. Hal ini disebabkan karena mayoritas responden masih berada pada umur yang sangat produktif yaitu antara 34-50 tahun atau sekitar $86 \%$ dari total responden.

Pada penelitian ini yang menjadi responden penelitian terbagi atas laki-laki dan perempuan. Data yang diperoleh dari hasil penelitian yaitu terlihat pada tabel, yaitu:

Tabel 5 Karakteristik Responden Berdasarkan Jenis Kelamin

\begin{tabular}{ccc}
\hline Jenis Kelamin & Jumlah & Persen (\%) \\
\hline Laki-laki & 4 & 19.05 \\
Perempuan & 17 & 80.95 \\
\hline & 21 & 100.00 \\
\hline
\end{tabular}

Sumber : hasil penelitian bulan April 2019

Berdasarkan Tabel 5 dapat dilihat bahwa jumlah responden mayoritas adalah perempuan, karena yang banyak menggeluti usaha mikro terutama penjual kuliner adalah perempuan. UPZ Unib menetapkan perempuan sebagai mustahik untuk menerima bantuan modal usaha bertujuan untuk menciptakan keluarga yang produktif dengan mengikutsertakan ibu rumah tangga untuk memulai aktivitas yang produktif. Sementara laki-laki memang sudah seharusnya dan menjadi tanggung jawab mereka sebagai kepala keluarga yang berusaha memenuhi kebutuhan keluarganya. Terlihat bahwa tingkat pendidikan responden tidaklah sama, tingkat pendidikan responden seperti yang terlihat pada tabel dibawah ini;

Tabel 6 Karakteristik Responden Berdasarkan Tingkat Pendidikan

\begin{tabular}{ccc}
\hline Tingkat Pendidikan & Jumlah (Orang) & Persen (\%) \\
\hline Tidak Sekolah & 1 & 4.76
\end{tabular}




\begin{tabular}{lcc}
\hline \multicolumn{1}{c}{ Tingkat Pendidikan } & Jumlah (Orang) & Persen $(\%)$ \\
\hline Sekolah Dasar & 1 & 4.76 \\
Sekolah Menengah Pertama & 2 & 9.52 \\
Sekolah Menengah Atas & 15 & 71.43 \\
Perguruan Tinggi & 2 & 9.52 \\
\hline \multicolumn{1}{c}{ Total } & 21 & 100.00 \\
\hline
\end{tabular}

Sumber : hasil penelitian bulan April 2019

Pada Tabel 6 dapat dilihat bahwa 4,76\% atau sebanyak 1 orang tidak sekolah dan juga hanya tamat Sekolah Dasar. Untuk tingkat Sekolah Menengah pertama sebanyak 9,52\% atau sebanyak 2 orang. Tamatan Sekolah Menengah Atas memiliki persentase dengan jumlah tertinggi yaitu 71,43\% atau sebanyak 15 orang dari seluruh responden. Sementara itu juga terdapat 9,52\% atau 2 orang yang memiliki pendidikanya di tingkat perguruan tinggi. Kondisi mengindikasikan belum meratanya pendidikan.

Berdasarkan hasil penelitian yang telah dilakukan maka dapat dilihat bahwa frekuensi penerimaan bantuan dana zakat responden tidaklah sama, frekuensi penerimaan bantuan dana zakat responden seperti yang terlihat pada tabel dibawah ini:

Tabel 7 Karakteristik Responden Berdasarkan Frekuensi Penerimaan

\begin{tabular}{ccc}
\hline Frekunsi Penerimaan & Jumlah & Persen (\%) \\
\hline 1 & 6 & 28,6 \\
2 & 6 & 28,6 \\
3 & 5 & 23,8 \\
4 & 2 & 9,5 \\
5 & 2 & 9,5 \\
\hline Total & 21 & $100.00 \%$ \\
\hline
\end{tabular}

Sumber : Dari hasil penelitian (2019)

Dilihat dari tabel 7 responden terbanyak yang mendapatkan dana bantuan adalah pada frekuensi 1 dan 2 yaitu masing-masing sebesar 28,6\%. Sementara responden yang telah diberikan pada frekuensi 3 ada sebesar 23,8\%, dan pada frekuensi 4 dan 5 masing-masing hanya 9,5\%.

Tabel 8 Karakteristik Responden berdasarkan Jenis usaha dan Jumlah keluarga

\begin{tabular}{ccc}
\hline No Responden & Jenis Usaha & Jumlah Keluarga \\
\hline 1 & Penjual Pempek & 3 \\
2 & Penjual Sayuran & 5 \\
3 & Penjual Sayuran & 4 \\
4 & Penjual Daging Ayam & 4 \\
5 & Penjual Sayuran & 3 \\
6 & Penjual Sayuran & 5 \\
7 & Kantin Sekolah & 5 \\
8 & Kantin Sekolah & 3 \\
9 & Kantin Sekolah & 6 \\
10 & Penjual Siomay & 2 \\
11 & Penjual Pop Ice & 6 \\
12 & Kantin Sekolah & 6 \\
13 & Kantin Sekolah & 4 \\
14 & Kantin Sekolah &
\end{tabular}




\begin{tabular}{ccc}
\hline No Responden & Jenis Usaha & Jumlah Keluarga \\
\hline 15 & Kantin Sekolah & 6 \\
16 & Kantin Sekolah & 5 \\
17 & Penjual Molen Mini & 3 \\
18 & Warung & 6 \\
19 & Penjual Lontong & 7 \\
20 & Penjual Susu & 4 \\
21 & Warung & 4 \\
\hline
\end{tabular}

Sumber : Dari hasil penelitian (2019)

Dari hasil penelitian terlihat usaha yang dijalankan mustahik terbagi dalam beberapa jenis usaha, yang terbanyak adalah jenis usaha kantin di sekolah dan selanjutnya adalah jenis usaha penjual sayuran.

Perkembangan Modal Usaha

Berdasarkan Tabel 9 menjelaskan besaran pertambahan modal usaha yang digunakan mustahik yang diterima untuk menjalankan usahanya, pertambahan masing-masing mustahik tidak sama hal ini dikarenakan pemberian bantuan modal yang sebesar Rp. 1.000.000, Rp. 1.500.000, Rp. 2.000.000, dan Rp. 3.000.000 tidak semua mustahik menggunakannya untuk menambah modal dalam menjalankan usahanya, sebagian menggunakan dana bantuan tersebut untuk kebutuhan rumah tangga mereka yang lain. Sebagian mustahik juga sudah mendapatkan bantuan lebih dari satu kali karena mereka telah mengembalikan bantuan pertama yang telah diberikan. Perekembangan persentase modal usaha yang dijalankan oleh mustahik setelah menerima bantuan modal mengalami peningkatan. Bantuan dana zakat produktif untuk modal yang diberikan oleh pihak Unit Pengumpul Zakat Universitas Bengkulu membantu mustahik dalam mengatasi kekurangan modal yang terjadi. Dari Tabel 9 perkembangan tertinggi ada 2 responden yaitu pada mustahik No. 2,4 dan 11 dengan perkembangan sebesar 100\%, sedangkan yang terendah adalah $12.82 \%$ mustahik No. 15, dan rata-rata perkembangan modal usaha dari 21 responden mustahik tersebut yaitu 43,53\%.

Tabel 9. Perkembangan Modal Usaha Sebelum dan Sesudah Menerima Dana Zakat Produktif.

\begin{tabular}{cccc}
\hline No Responden & $\begin{array}{c}\text { Modal Sebelum } \\
\text { Menerima } \\
\text { Bantuan/Bulan } \\
\mathbf{( R p )}\end{array}$ & $\begin{array}{c}\text { Modal Setelah } \\
\text { Menerima } \\
\text { Bantuan/Bulan }(\mathbf{R p})\end{array}$ & $\begin{array}{c}\text { Persentase } \\
\text { Pertumbuhan Modal } \\
(\mathbf{\%})\end{array}$ \\
\hline 1 & $3,300,000$ & $4,300,000$ & 30.30 \\
2 & $2,000,000$ & $4,000,000$ & 100.00 \\
3 & $3,000,000$ & $4,000,000$ & 33.33 \\
4 & $1,500,000$ & $3,000,000$ & 100.00 \\
5 & $1,500,000$ & $2,500,000$ & 66.67 \\
6 & $6,000,000$ & $7,000,000$ & 16.67 \\
7 & $5,000,000$ & $7,500,000$ & 50.00 \\
8 & $9,100,000$ & $10,400,000$ & 14.29 \\
9 & $5,200,000$ & $7,800,000$ & 50.00 \\
10 & $5,000,000$ & $7,500,000$ & 50.00 \\
11 & $1,000,000$ & $2,000,000$ & 100.00 \\
12 & $7,800,000$ & $10,400,000$ & 33.33 \\
13 & $1,500,000$ & $2,500,000$ & 66.67 \\
14 & $2,000,000$ & $2,600,000$ & 30.00 \\
\hline
\end{tabular}




\begin{tabular}{cccc}
\hline No Responden & $\begin{array}{c}\text { Modal Sebelum } \\
\text { Menerima } \\
\text { Bantuan/Bulan } \\
\mathbf{( R p )}\end{array}$ & $\begin{array}{c}\text { Modal Setelah } \\
\text { Menerima } \\
\text { Bantuan/Bulan }(\mathbf{R p})\end{array}$ & $\begin{array}{c}\text { Persentase } \\
\text { Pertumbuhan Modal } \\
\mathbf{( \% )}\end{array}$ \\
\hline 15 & $7,800,000$ & $8,800,000$ & 12.82 \\
16 & $4,000,000$ & $5,000,000$ & 25.00 \\
17 & $3,900,000$ & $5,000,000$ & 28.21 \\
18 & $5,000,000$ & $6,000,000$ & 20.00 \\
19 & $3,000,000$ & $4,000,000$ & 33.33 \\
20 & $4,800,000$ & $6,000,000$ & 25.00 \\
21 & $3,500,000$ & $4,500,000$ & 28.57 \\
\hline Rata-rata & & & 43.53 \\
\hline Sumber $:$ Dari hasil penelitian $(2019$ & &
\end{tabular}

Hampir seluruh responden mengalami kenaikan atau perkembangan pendapatan, namun hanya penerimaan modal pertama yang rata-rata yang digunakan untuk penambahan modal usaha.

Perkembangan Omset Usaha

Dengan melihat besaran omset atau perkembangan omset juga dapat menentukan apakah usaha tersebut mengalami peningkatan atau malah sebaliknya. Perkembangan omset usaha mustahik dapat dilihat dari Tabel 10.

Tabel 10. Perkembangan Omset Usaha Sebelum dan Setelah Menerima bantuan Dana Zakat Produktif

\begin{tabular}{cccc}
\hline No Responden & $\begin{array}{c}\text { Omset Sebelum } \\
\text { Menerima } \\
\text { Bantuan/Bulan (Rp) }\end{array}$ & $\begin{array}{c}\text { Omset Setelah } \\
\text { Menerima } \\
\text { Bantuan/Bulan }(\mathrm{Rp})\end{array}$ & $\begin{array}{c}\text { Persentase } \\
\text { pertumbuhan Omset } \\
(\%)\end{array}$ \\
\hline 1 & $4,500,000$ & $6,000,000$ & 33.33 \\
2 & $3,200,000$ & $5,250,000$ & 64.06 \\
3 & $6,000,000$ & $9,000,000$ & 50.00 \\
4 & $2,500,000$ & $4,500,000$ & 80.00 \\
5 & $2,100,000$ & $3,250,000$ & 54.76 \\
6 & $6,700,000$ & $7,800,000$ & 16.42 \\
7 & $7,500,000$ & $12,000,000$ & 60.00 \\
8 & $11,700,000$ & $15,000,000$ & 28.21 \\
9 & $7,800,000$ & $13,000,000$ & 66.67 \\
10 & $6,400,000$ & $9,000,000$ & 40.63 \\
11 & $1,650,000$ & $2,600,000$ & 57.58 \\
12 & $10,400,000$ & $13,000,000$ & 25.00 \\
13 & $2,000,000$ & $3,200,000$ & 60.00 \\
14 & $4,500,000$ & $6,500,000$ & 44.44 \\
15 & $9,100,000$ & $10,400,000$ & 14.29 \\
16 & $4,600,000$ & $5,760,000$ & 25.22 \\
17 & $5,200,000$ & $7,020,000$ & 35.00 \\
18 & $6,000,000$ & $7,500,000$ & 25.00 \\
19 & $4,500,000$ & $6,000,000$ & 33.33 \\
20 & $8,000,000$ & $10,000,000$ & 25.00 \\
21 & $4,600,000$ & $6,300,000$ & 36.96 \\
\hline Rata-rata & & & $41.71 \%$ \\
\hline Sumber $:$ Darihasil penelitian $(2019)$ & &
\end{tabular}

Sumber : Dari hasil penelitian (2019) 
Berdasarkan Tabel 10 dapat dilihat perkembangan omset usaha mustahik penerima bantuan dana zakat profuktif. Untuk perkembangan omset terbesar yaitu $80.00 \%$ yaitu responden dengan No. 4 dimana omset sebelum menerima adalah Rp 2.500 .000 kemudian setelah menerima bantuan modal menjadi 4.500 .000 kemudian selanjutnya adalah mustahik No. 9 dengan perkembangan $66.67 \%$ yaitu omset sebelum menerima adalah Rp. 7.800.000 dan setelah menerima bantuan modal adalah Rp. 13.000.000,. sedangkan untuk omset dengan perkembangan terkecil adalah mustahik dengan No. 15 yaitu $14.29 \%$ dengan omset sebelum Rp. 9.100 .000 dan setelah menerima bantuan menjadi Rp. 10.400.000. untuk rata-rata perkembangan omset usaha mustahik adalah sebesar $41.71 \%$.

\section{Perkembangan Keuntungan Usaha}

Pengertian secara umum keuntungan adalah hasil pengurangan omset dan modal atau keuntungan adalah perbedaan antara pendapatan dan biaya atau beban. Jika pendapatan melebihi biaya atau beban maka keuntungan yang didapat namun jika sebaliknya maka kerugian yang dialami. Setiap usaha yang dilakukan pasti mengharapkan keuntungan dari usaha yang dijalankan. Perkembangan keuntungan usaha mustahik dapat dilihat dalam Tabel 11.

Tabel 11 Perkembangan Keuntungan Usaha Mustahik Sebelum Dan Setelah Menerima Bantuan Dan Zakat Produktif

\begin{tabular}{cccc}
\hline No Responden & $\begin{array}{c}\text { Keuntungan Sebelum } \\
\text { Menerima } \\
\text { Bantuan/Bulan }(\mathbf{R p})\end{array}$ & $\begin{array}{c}\text { Keuntungan Setelah } \\
\text { Menerima } \\
\text { Bantuan/Bulan }(\mathbf{R p})\end{array}$ & $\begin{array}{c}\text { Persentase } \\
\text { Pertumbuhan } \\
\text { Keuntungan }(\%)\end{array}$ \\
\hline 1 & $1,200,000$ & $1,700,000$ & 41.67 \\
2 & $1,200,000$ & $1,250,000$ & 4.17 \\
3 & $3,000,000$ & $5,000,000$ & 66.67 \\
4 & $1,000,000$ & $1,500,000$ & 50.00 \\
5 & 600,000 & 750,000 & 25.00 \\
6 & 700,000 & 800,000 & 14.29 \\
7 & $2,500,000$ & $4,500,000$ & 80.00 \\
8 & $2,600,000$ & $4,600,000$ & 76.92 \\
9 & $2,600,000$ & $5,200,000$ & 61.54 \\
10 & $1,400,000$ & $1,500,000$ & 7.14 \\
11 & 650,000 & 600,000 & -7.69 \\
12 & $2,600,000$ & $2,600,000$ & 0.00 \\
13 & 500,000 & 700,000 & 40.00 \\
14 & $2,500,000$ & $3,900,000$ & 56.00 \\
15 & $1,300,000$ & $1,600,000$ & 23.08 \\
16 & 600,000 & 760,000 & 26.67 \\
17 & $1,300,000$ & $2,020,000$ & 55.38 \\
18 & $1,000,000$ & $1,500,000$ & 50.00 \\
19 & $1,500,000$ & $2,000,000$ & 33.33 \\
20 & $3,200,000$ & $4,000,000$ & 25.00 \\
21 & $1,100,000$ & $1,800,000$ & 63.64 \\
\hline
\end{tabular}

Sumber : Dari hasil penelitian (2019)

Berdasarkan Tabel 11 dapat dilihat bahwa tidak semua mustahik mengalami peeningkatan keuntungan usaha yang dijalankanya. Beberapa mustahik mengalami peningkatan, namun ada satu musthik yang pendapatannya malah menurun dari sebelum menerima bantuan, yaitu mustahik No. 11. Kemudian ada juga mustahik yang perkembangan keuntunganya tidak ada sama sekali atau $0 \%$ yaitu mustahik No. 12 dimana keuntungan sebelum dan sesudah menerima bantuan dana zakat produktif adalah sama. Sementara untuk perkembangan keuntungan terbesar yaitu dengan 
perkembangan sebesar $100.00 \%$ mustahik dengan No. 9, dimana sebelum menerima bantuan keuntungan usaha yang didapat adalah Rp. 2.600.000 menjadi Rp. 5.200.000 setelah menerima bantuan modal dana zakat produktif. Untuk nilai rata-rata perkembangan keuntungan usaha dari 21 mustahik adalah $39.58 \%$. Namun disini terdapat mustahik yang tidak mengalami pertumbuhan keuntungan bahkan menurun, yaitu responden dengan No 11 dengan perkembangan $-7.69 \%$ dan No 12 dengan perkembangan Keuntungan sebesar $0.00 \%$

Berdasarkan hasil wawancara yang dilakukan kepada pengurus Unit Pengumpul Zakat Universitas Bengkulu, penyaluran dana zakat produktif bertujuan untuk mengubah mustahik (penerima zakat) menjadi muzzaki (pemberi zakat). Tentunya penyaluran dana zakat produktif ini diberikan kepada mustahik yang telah memiliki usaha atau telah menjalankan usaha namun mengalami kendala dalam permodalan dalam bentuk bantuan modal usaha. Bagi mustahik yang ingin mendapatkan bantuan modal ini harus memenuhi kriteria atau ketentuan yang telah ditetapkan oleh Unit Pengumpul Zakat Unib yaitu telah memiliki atau telah menjalankan usaha minimal 2 tahun, hasil usaha tidak cukup untuk memenuhi kebutuhan sehari-hari, dan memiliki komitmen yang tinggi untuk menjalankan usaha dan juga untuk mengembangkan usaha serta melunasi bantuan dana yang diberikan. Jika para mustahik telah memenuhi kriteria yang telah ditetapkan maka penyaluran dana zakat produktif dalam bentuk bantuan modal usaha bisa didapatkan oleh mustahik.

Dalam memberikan bantuan modal usaha pihak UPZ Unib melakukan beberapa tahapan untuk menetapkan mustahik. Besaran penyaluran dana zakat produktif dalam bentuk modal usaha kepada setiap mustahik memiliki besaran yang sama yaitu Rp. 1.000.000, untuk kali pertama mustahik mendapatkan bantuan. Mustahik yang telah mendapatkan bantuan dana zakat produktif dalam bentuk bantuan modal usaha selanjutnya akan menerima pengawasan dana bantuan modal usaha dari pihak UPZ Unib. Seperti hasil wawancara yang telah dilakukan dengan pihak UPZ Unib mengatakan bahwa dilakukan bisa per satu minggu, per dua minggu atau per satu bulan. Pengawasan ini dilakukan secara langsung yang dilakukan dengan mendatangi mustahik secara langsung.

Untuk menyalurkan dana zakat produktif ada beberapa hal yang menjadi penghalang yaitu kurangnya pemahaman calon penerima bantuan dana zakat produktif akan dana bantuan itu sendiri, terkadang juga penggunaan dana bantuan tidak tepat sasaran, yang tujuan awal adalah untuk membantu persoalan permodalan mustahik dalam menjalankan usaha namun digunakan untuk kegiatan yang lainnya, seperti pemenuhan kebutuhan pokok rumah tangga, biaya anak sekolah, biaya bepergian, dan lainya. UPZ Unib berharap akan semakin meningkatnya bantuan dana zakat produktif yang dapat disalurkan, sehingga mampu menjangkau lebih banyak lagi calon mustahik untuk menerima bantuan tersebut. Dari hasil kuesioner yang diberikan kepada responden dana zakat produktif tersebut dapat membantu dalam meningkatkan pendapatan bagi mustahik.

Dari hasil penelitian juga mendapatkan informasi bahwa calon mustahik lebih memilih bantuan dana zakat produktif dari Unit Pengumpul Zakat Unib dari pada lembaga keungan lain, dikarenakan bantuan yang diberikan pengembaliannya tidak menggunakan bunga. Kemudian juga dalam proses pengembaliannya, mustahik dapat menentukan sendiri bagaimana prosesnya, terkait dengan berapa besaran cicilan yang akan dibayarkan dalam waktu yang juga ditetapkan sendiri berdasarkan kesepakatan dengan pihak UPZ Unib. Mustahik juga tidak diberikan kewajiban apapun jika benar-benar tidak mampu mengembalikan dana bantuan tersebut, sementara bagi mustahik yang telah mengembalikan bantuan secara lunas dapat mengajukan kembali bantuan dana zakat produktif tersebut.

Bantuan dana zakat produktif itu sendiri dapat mempengaruhi pendapatan serta tingkat kesejahteraan para mustahik dalam memenuhi kebutuhan serta tanggungan mustahik. Dalam penelitian ini dapat dikatakan bahwa bantuan dana zakat produktif berdampak terhadap usaha mustahik. Adanya bantuan dana zakat produktif sebagai suntikan dana bantuan modal sangat 
membantu terhadap perkembangan usaha mustahik, dan ini menunjukan bahwa zakat berpihak kepada orang miskin untuk mengurangi kemiskinannya dan meningkatkan kesejahteraanya.

Perbedaan dasar dana zakat yang disalurkan kepada seluruh mustahik dengan bantuan dari lembaga keuangan lainya adalah, dana zakat dari UPZ Unib merupakan pinjaman tanpa bunga. Bagi mustahik yang telah mendapatkan bantuan, kesepakatan pengembalian bantuan modal usaha dapat ditentukan sendiri, yaitu bisa dicicil dengan besaran yang mustahik sendiri tentukan dalam waktu juga mustahik sendiri yang menetukan, bisa per satu minggu, per 2 minggu atau per satu bulan. Namun bagi mustahik yang benar-benar tidak mampu mencicil bantuan modal usaha untuk pengembalian maka pihak UPZ Unib tidak akan memberikan tuntutan kepada mustahik tersebut atau menjadi bantuan cuma-cuma. Namun disisi lain, para mustahik juga diberikan motivasi dalam menjalankan usaha nya melalui pengawasan yang diberikan oleh UPZ Unib, hingga para mustahik memiliki beban moral. Selain itu diharapkan produktivitas para mustahik lebih tinggi, karena tidak harus memikirkan hutang yang mereka miliki. Bagi mustahik yang telah melunasi bantuan modal usaha yang diberikan oleh UPZ Unib dapat mengajukan bantuan modal kembali dengan nominal yang bisa disesuaikan dengan kebutuhan menjalankan usaha, tidak sedikit mustahik yang mengajukan bantuan kembali dengan nominal yang berbeda-beda, mulai dari Rp. 1.000.000., Rp. 1.500.000., Rp. 2.500.000 dan Rp. 2.500.000. hingga Rp. 3.000.000. Dari hasil penelitian didapatkan bahwa tidak ada penerima yang tidak mengembalikan dan bantuan yang telah diberikan.

a. Dampak Penyaluran Dana Zakat Produktif Terhadap Usaha Mustahik Dilihat Dari Perkembangan Modal Usaha

Pada tabel 1.2 adalah data perkembangan modal usaha mustahik. Dari tabel 1.2. Dijelaskan bahwa perkembangan usaha yang dilihat dari modal yang diterima oleh mustahik dalam menjalankan usahanya. Besaran modal yang diterima oleh mustahik yaitu Rp. 1.000.000, Rp. 1.500.000, Rp. 2.000.000 dan Rp. 3.000.000. Dari tabel 4.12. Terlihat terdapat 3 responden yang mendapatkan pertumbuhan modal paling besar yaitu 100\%, pada responden No 2 dan 11 berdasarkan penelitian menggunakan seluruh dana bantuan yang diterima untuk menambah modal, tapi responden juga menambah modalnya dengan dana pribadi sebesar $25 \%$.

Responden dengan nomor 2 menggunakan dana yang diterima untuk membeli bahan-bahan untuk memperbanyak produksinya, sementara pada responden nomor 11 juga menggunakan bantuan dana yang diterima untuk menambah produksi hasil usahanya. Sementara untuk responden No. 4 hanya menggunakan $75 \%$ dari total bantuan dana yang diberikan untuk menambah modal, yaitu untuk membeli bahan-bahan pokok untuk usahanya. Kemudian terdapat responden lain yang juga tidak menggunakan seluruh dana zakat yang diberikan untuk menambah modal yaitu responden dengan No. 1 sebesar 33\%, No. sebesar 50\%, No. 6 sebesar 50\%, No.8 sebesar 87\%, No. 14 sebesar 40\%, No. 16 sebesar 67\%, dan No. 20 hanya 40\%. Dana zakat lainnya tidak digunakan untuk keperluan modal usaha, namun digunakan untuk keperluan lainya. Hal ini menunjukan masih banyak mustahik yang tidak bijak dalam menggunakan bantuan dana zakat yang telah diberikan. Dari hasil penelitian ditemukan beberapa responden yang menggunakan dana bantuan usaha yang diberikan untuk memenuhi keperluan rumah tangga, biaya sekolah anak.

Kemudian juga terdapat responden yang menambah modal yang digunakan untuk keperluan usaha nya menggunakan dana pribadi yang mereka miliki sendiri, hal ini dikarenakan keperluan dana yang dibutuhkan belum ter cover dari dana bantuan yang diberikan oleh UPZ Unib yaitu responden dengan No. 7 menambah modal nya 40\% dari dana pribadi, No. 9 sebesar 42\%, No. 10 sebesar 20\%, dan No. 12 menggunakan dana pribadi $23.08 \%$ dari total pertambahan modal yang digunakan untuk keperluan usaha. Sementara responden lainya menggunakan dengan bijak dana zakat yang diberikan, yaitu $100 \%$ digunakan untuk menambah modal usaha. 
b. Dampak Penyaluran Dana Zakat Produktif Terhadap Usaha Mustahik Dilihat Dari Perkembangan Omset Usaha

Dari hasil penelitian pada tabel 1.3. Terlihat bahwa semua mustahik mengalami perkembangan omset usaha, perkembangan omset terbesar adalah responden dengan No. 4 yaitu 80\%, dan hanya menggunakan $75 \%$ dana zakat yang diberikan responden dengan jenis usaha menjual daging, responden dengan nomor 4 telah menerima bantuan dana zakat yang ke empat kalinya. Sementara untuk responden dengan perkembangan omset terkecil adalah responden dengan No. 15 yaitu $14.29 \%$ dana zakat yang digunkan untuk menambah modal usaha $100 \%$ dan jenis usaha nya adalah kantin sekolah, responden dengan nomor 15 telah menerima bantuan dana zakat yang ke kedua kalinya, dan No. 6 hanya $16.42 \%$, jenis usaha penjual sayuran dan dana zakat yang digunakan adalah 50\% dan telah menerima bantuan yang kelima kalinya. Kemudian untuk responden yang menambah modal usaha juga dari dana pribadi mereka juga mendapatkan perkebangan omset yang tinggi yaitu responden dengan No. 2 sebesar $64.06 \%$, No. 7 sebesar $60.00 \%$, No. 5 sebesar $66.67 \%$, No. 10 sebesar $40.63 \%$, dan No. 12 mendapatkan omset $25 \%$.

Terlihat berdasarkan hasil penelitian, semakin besar modal usaha yang digunakan akan mengakibatkan perkembangan omset yang semakin besar, namun terlihat juga pada besaran diatas Rp. 2.000.000 omset yang didapatkan cenderung menurun perkembangannya dibandingkan dengan Rp. 2.000.000 ke bawah, hal ini disebabkan banyak dana bantuan yang digunakan untuk keperluan lainya. Berdasarkan hasil penelitian menunjukan bahwa jenis usaha kantin di sekolah menghasilkan rata-rata perkembangan yang tinggi.

\section{c. Dampak Penyaluran Dana Zakat Produktif Terhadap Usaha Mustahik Dilihat Dari Perkembangan Keuntungan Usaha}

Berdasarkan tabel 1.4, responden yang mengalami perkembangan keuntungan tertinggi adalah responden dengan No. 9 yaitu mencapai $100 \%$ dengan jenis usaha kantin sekolah, hal ini juga disebabkan karena responden tersebut menggunakan $100 \%$ dana zakat yang diberikan dan menambah $43 \%$ dari dana pribadi. Kemudian juga responden tersebut telah mendapatkan bantuan dana modal yang ke tiga kalinya. Responden dengan perkembangan omset terbesar selanjutnya adalah responden dengan No. 7 yaitu mencapai $80 \%$ dengan jenis usaha kantin sekolah, hal ini juga disebabkan karena responden menambah modal dari dana pribadi yaitu sebesar $40 \%$ dan juga telah mendapatkan bantuan dana modal yang ketiga kalinya dari UPZ Unib.

Sementara untuk responden dengan perkembangan terkecil yaitu responden No. 11 dan jenis usaha adalah menjual pop ice, dan telah menggunakan $100 \%$ dana zakat yang diberikan, perkembangan keuntunganya yaitu $-7 \%$, hal ini dikarenakan sedang terjadi penurunan penjualan dan juga dana bantuan modal yang didapat digunakan untuk menambah peralatan produksi baru untuk mengganti peralatan lama yang mengalami kerusakan dan juga menurunya penjualan yang diakibatkan musim hujan yang sedang berlangsung, hingga omset yang didapatkan oleh responden tidak maksimal. Semantara itu juga terdapat responden yang tidak mengalami perkembangan keuntungan usaha nya atau perkembangan keuntungan usahanya sebesar $0 \%$, yaitu responden dengan No. 12, dengan jenis usaha kantin sekolah, meski telah menambah modal dengan dana pribadi sebesar $23.08 \%$ tapi tetap tidak menambah perkembangan keuntungannya, hal ini disebabkan juga karena responden yang memiliki usaha kantin disekolah tersebut menambah alat-alat yang digunakan untuk menjalankan usahanya dan responden juga telah mendapatkan bantuan dana modal yang kedua kalinya.

Untuk rata-rata perkembangan keuntungan usaha dari seluruh mustahik yang menerima dana zakat produktif dalam bentuk bantuan dana zakat produktif yaitu sebesar $37.75 \%$ hal ini menunjukan dana zakat produktif berdampak bagi usaha para mustahik. Kemudian juga didapatkan bahwa volume penerimaan mempengaruhi perkembangan usaha mustahik, dari hasil penelitian 
didapatkan volume terbaik untuk memberikan bantuan dana zakat adalah 3 atau 4 kali, namun juga tidak baik jika terlalu sering, karena akan melalaikan dana bantuan modal yang diberikan untuk keperluan lainya. Bantuan juga tidak cukup satu kali, karena ini terlalu sedikit bagi pemilik usaha untuk mengembangkan usahanya. Dari hasil penelitian yang telah dilakukan rata-rata yang mendapatkan perkembangan tertinggi adalah jenis usaha kantin di sekolah, oleh karena itu diaharapkan para pemberi zakat ataupun pengelola UPZ Unib dapat memaksimalkan bantuan yang diberikan kepada pemilik usaha kantin disekolah. Tentu hal ini disebabkan karena konsumen dari usaha mereka suda ada dan sudah diketahui kebutuhan yang mereka inginkan.

\section{KESIMPULAN}

Berdasarkan tujuan penelitan yang telah dipaparkan yaitu untuk mengetahui dampak alokasi dana zakat terhadap usaha ekonomi penerima (Mustahik) yang diberikan oleh UPZ yaitu perkembangan modal, perkembangan omset dan perkembangan keuntungan, dan juga berdasarkan hasil penelitian dan pembahasan, maka dapat dimpulkan sebagai berikut:

1. Alokasi dana zakat terhadap usaha ekonomi penerima (Mustahik) yang diberikan oleh UPZ memiliki dampak terhadap perkembangan modal usaha mustahik (penerima zakat) yaitu dengan rata-rata $43.53 \%$.

2. Alokasi dana zakat terhadap usaha ekonomi penerima (Mustahik) yang diberikan oleh UPZ memiliki dampak terhadap perkembangan omset usaha mustahik (penerima zakat) yaitu dengan rata-rata $41.71 \%$.

3. Alokasi dana zakat terhadap usaha ekonomi penerima (Mustahik) yang diberikan oleh UPZ memiliki dampak terhadap perkembangan keuntungan usaha mustahik (penerima zakat) yaitu dengan rata-rata $37.75 \%$.

Rekomendasi untuk penelitian lanjutan yang diberikan berdasarkan hasil penelitian ini adalah penelitian selanjutnya dapat melihat dampak dari seluruh jenis penyaluran zakat yang telah dilakukan, agar tergambar dengan jelas bagaimana peran zakat dalam kondisi penerimanya, kemudian juga dapat dilakukan penelitian untuk melihat kinerja dari badan yang mengelola zakat yaitu UPZ Unib apakah sudah berjalan dengan baik atau sebaliknya.

\section{DAFTAR PUSTAKA}

Adi, M kwartono. 2007. Analisis Usaha Kecil Menengah. Yogyakarta: Andi Offset

Aflah, Noor. 2009. Arsitektur zakat Indonesia. Jakarta : Penerbit Universitas Indonesia.

Al-Ba'ly, Abdul Al-Hamid Mahmud. 2006. Ekonomi Zakat : Sebuah Kajian Moneter dan Keuangan Syariah. Jakarta : PT Raja Grafindo Persada.

Ali, Nurudin, Mhd. 2006. Zakat Sebagai Instrumen Dalam Kebijakan Fiskal. Jakarta : PT Raja Grafindo Persada.

Bahri, Andi. 2016. Zakat Sebagai Instrumen Pembangunan Ekonomi Kesejahteraan Ummat. Jurnal Studi Ekonomi dan Bisnis Islam, I, 16 (2) : 74-88

Beik, Irfan Syauqi. 2009. Analisis Peran Zakat dalam Mengurangi Kemiskinan : Studi Kasus Dompet Dhuafa Republika. Jurnal Pemikiran dan Gagasan, 09 (2)

Canggih ,Clarashinta, Khusnul Fikriyah, Ach. Yasin. 2017. Potensi Dan Realisasi Dana Zakat Indonesia. Journal of IslamicEconomics, 1, 17 (1) : 14-26

Damanhur, Nurainiah. 2016. Analisis Pengaruh Bantuan Zakat Terhadap Tingkat Kesejahteraan Masyarakat Kabupaten Aceh Utara. Jurnal Visioner Strategis, 5, 16 (2) : 71-82 
Dianto, Ageng Mei. 2014. Peranan Lembaga Amil Zakat Nasional Baitul Maal Hidayatullah Dalam Meningkatkan Kesejahteraan Mustahiq Kabupaten Tulungagung, 14 (1) : 138-157

Gusfahmi. 2007. Pajak Menurut Syariah. Jakarta : Rajawali Press

Hafidhuddin, Didin. 2007. Agar Harta Berkah Dan Bertambah : Gerakan Membudayakan Zakat, Infaq Dan Sedekah, Dan Wakaf. Cetakan 1. Jakarta: Gema insani

Kuncoro, mudrajad. 2009. Metode Riset Untuk Bisnis Dan Ekonomi. Yogyakarta: Erlangga

Madani, El. 2013. Fiqih Zakat Lengkap : Segala Hal Tentang Zakat Dan Cara Membaginya. Jakarta : Diva Press.

Mankiw, N. Gregory. 2003. Pengantar Ekonomi. Jakarta : Erlangga.

Mubarok, Abdullah, dan baihaqi, F. 2014. Penghimpunan Dana Zakat Nasional (Potensi, Realisasi dan Peran Penting Organisasi Pengelola Zakat). PERMANA, 14 (2) : 7-14

Muhammad, Sahri. 2006. Mekanisme Zakat Dan Permodalan Masyarakat : Pengantar Untuk Rekonstruksi Kebijakan Pertumbuhan Ekonomi, Cetakan 1. Malang: Bahtera Press

Muhammad. 2002. Zakat Profesi : Wacana pemikiran zakat dalam zakat dalam fiqih kontemporer. Jakarta : Salemba Diniyah.

Muhammad. 2017. Lembaga Perekonomian Islam (Persepektif Hukum, Teori, dan Aplikasi. Yogyakarta : Upp Stim Ykpn.

Maulana Rizky Maulana, Asep Ramdan Hidayat, Zainal Abdul Malik. 2011. Optimalisasi pendayagunaan Zana Zakat Produktif Dalam Pemberdayaan Mustahiq Zakat di PKPU Kota Bandung. Jurnal Hukum Islam, 15 (6) : 123 -127

Rosydi, suherman. 2011. Pendekatan Kepada Ekonomi Mikro Dan Makro. Jakarta : Rajawali Pers.

Sodiman, Mustafa P, Muhammad Hadi, Ahmadi dan La Hadisi. 2016. Potensi Dan Efektivitas Pengelolaan Zakat Di Kabupaten Konawe Selatan. Jurnal Studi Ekonomi dan Bisnis Islam, I, $16(2): 54-70$

Winarni, Sri. 2006. Strategi Pengembangan Usaha Kecil Melaui Peningkatan Aksesibilas Kredit Perbankan. Jurnal Infokop. 11 (29)

Yasin, ach, Clarashinta Canggih, Khusnul Fikriyah. 2017. Potensi Dan Realisasi Dana Zakat Indonesia. Journal Of Islamic Economics. 17 (1) : 14-26

Yunanto. 2010. Analisis Potensi, Upaya Pajak, Efisiensi, Efektivitas Dan Elastisitas Pajak Hotel Di Kabupaten Klaten. Surakarta : Tesis Program Pascasarjana Universitas Sebelas Maret. (http://eprints.uns.ac.id diakses 12 Januari 2019)

Yustika, Ahmad Erani. 2008. Ekonomi Kelembagaan : Definisi, Teori, dan Strategi. Malang : Bayumedia 